\title{
Epidemiological Profile of Thoracic Trauma in Brazil: A Systematic Review
}

\author{
Gabriel A Roberto ${ }^{1}$, Carolina M Britto Rodrigues ${ }^{2}$, Sthefano A Gabriel ${ }^{3}$, Rodrigo A Sardenberg ${ }^{4}$
}

\begin{abstract}
Background: One of the main injuries found in traumatized patients is thoracic trauma (TT) and corresponds to $25 \%$ of deaths in polytrauma patients. According to the World Health Organization, more than nine people die per minute from some type of trauma, with an expense equivalent to $12 \%$ for all diseases.

Materials and methods: This is a study that addresses the epidemiology of TT in Brazil through a systematic review of the literature on TT in Brazil, conducted in electronic databases following the guidelines of Preferred Notification Items for Systematic Reviews and Meta-analyses (PRISMA). Exclusion criteria were: case reports of other causes of trauma, animal studies, literature reviews, and studies that did not cover chest trauma. The Statistical Package for Social Sciences (SPSS) version 21.0 was used to analyze the results.

Results: Initially, 760 studies were found, of which 36 articles were selected as relevant to the study on the epidemiological characteristics of TT. With a high global prevalence, trauma is considered a public health problem, associated with high morbidity and mortality, in developed and developing countries.

Interpretation: The Southeast Region had greater statistical relevance $(p=0.033)$ for mechanisms and causes of TT. The penetrating chest trauma [gunshot wounds (GSW) and stab wounds (SW)], showed greater statistical relevance in the South $(p=0.04)$ and Midwest $(p=0.04)$, among the other regions, the value was $(p \geq 0.5)$.
\end{abstract}

Keywords: Thoracic trauma, Trauma, Trauma epidemiology thoracic lesions, Trauma in Brazil.

Panamerican Journal of Trauma, Critical Care \& Emergency Surgery (2021): 10.5005/jp-journals-10030-1306

\section{INTRODUCTION}

Thoracic trauma (TT) is part of the main injuries found in trauma patients and corresponds to $25 \%$ of deaths in polytraumatized patients. ${ }^{1,2}$ According to the World Health Organization (WHO), over nine people die per minute from some type of trauma, with a health expense equivalent to $12 \%$ to all diseases. ${ }^{3-5}$ External causes are closely related to TT, such as physical assault, automobile accidents, and other forms of urban accidents, which are the third leading cause of death in Brazil, corresponding to $12.5 \%$ of all deaths in the country. ${ }^{2}$ With high global prevalence, trauma is considered a public health problem, associated with high morbidity and mortality, in developed and developing countries.

Since 1980, deaths from external causes have increased in Brazil. However, the Brazilian Public Health System (SUS) only adhered to the codification of diseases in a data system in 1997. ${ }^{6}$ Thus, information has become essential for monitoring and creating means of prevention of this serious reality in the country. ${ }^{7}$ The national policy for the Reduction of Morbidity and Mortality from Accidents and Violence, established by Ordinance No 737/GM by the Ministry of Health May 2001, proposes preventive measures against accidents and violence, in addition to ensuring the treatment of the victims. ${ }^{8}$

Thoracic trauma is classified as being either blunt or penetrating. The most common cause of blunt trauma is motor vehicle collision (MVC), which is responsible for up to $80 \%$ of the injuries. Other circumstances include crashes, vehicles hitting pedestrians, acts of violence, and explosion injuries. Most penetrating injuries are due to gunshot wounds (GSW) and stab wounds (SW), which together account for $20 \%$ of all serious trauma in the United States. ${ }^{1,9,10}$

Treatment of most thoracic lesions is done through chest tube thoracostomy associated with analgesia and ventilatory \begin{tabular}{l}
\hline \hline${ }^{1-3}$ Department of CEPAM, União das Faculdades dos Grandes Lagos- \\
UNILAGO, São José do Rio Preto, São Paulo, Brazil \\
${ }^{4}$ Department of CEPAM, União das Faculdades dos Grandes Lagos- \\
UNILAGO, São José do Rio Preto, São Paulo, Brazil; German Hospital \\
Oswaldo Cruz, São Paulo, Brazil
\end{tabular}

Corresponding Author: Gabriel A Roberto, Department of CEPAM, União das Faculdades dos Grandes Lagos - UNILAGO, São José do Rio Preto, São Paulo, Brazil, Phone: +55 17996523908, e-mail: contatogabrielroberto@gmail.com

How to cite this article: Roberto GA, Britto Rodrigues $C M$, Gabriel SA, et al. Epidemiological Profile of Thoracic Trauma in Brazil: A Systematic Review. Panam J Trauma Crit Care Emerg Surg 2021;10(1): 31-38.

Source of support: Nil

Conflict of interest: None

support. Only $15-30 \%$ of TT need thoracotomy or other invasive intervention. ${ }^{10-15}$ In the United States, $<10 \%$ of blunt trauma requires surgical intervention, while in open trauma $15-30 \%$ will require surgery. ${ }^{1}$

This study aims to provide an epidemiological analysis of TT in Brazil by means of a systematic review.

\section{Materials and Methods}

A systematic review addressing TT in Brazil was conducted in the electronic databases of PUBMED/NCBI, SciELO, LILACS, MEDLINE, WHOLIS, COCHRANE, and WHO. The analysis also based its results through System of Death Information (SIM), which is the computing department of the Brazilian Public Health System (SUS), following 
the Preferred Reporting Items for Systematic Reviews and MetaAnalyses (PRISMA) guidelines. The search took place by articles published from January 2008 to January 2018 using the keywords "Injuries", "Thoracic Trauma”, “Drainage”, "Thorax", "Pneumothorax", "Hemothorax", "Epidemiology", "Traumatology Centers", "Cardiac Trauma", "Penetrating Wounds", and "Chest Trauma". Three variables present in external causes were analyzed: transport accidents (TA), intentionally self-inflicted injuries (ISII), and aggressions (AGRs). The analysis includes researches published in Portuguese and English.

The following exclusion criteria were applied: case reports of other trauma causes, animal studies, reviews of the literature, and studies that did not cover TT.

The Statistical Package for Social Sciences (SPSS) version 21.0 was utilized to analyze the results. The patients were divided into three groups according to the type of death from external causes [traffic accidents (TA), ISII, and AGRs] which were compared employing the Kruskal-Wallis test. $p$ values $<0.05$ were considered statistically significant.

\section{Results}

Initially, 760 studies were identified in the databases searched (390 in SciELO, 37 in LILACS, 108 in PUBMED, 35 in WHOLIS, and 490 in COCHRANE). Following exclusion based on title and abstract, 133 articles were selected for full-text analysis. Finally, 36 articles were selected as relevant to the present study on the TT epidemiological characteristics as shown in Flowchart 1. The findings by regions were also described (Table 1).

Describing the main characteristics of TT in the North, Westphal and Luiz showed that penetrating TT with a lethal anatomical score (>15 points) associated with important vascular lesions, such as the aorta and vena cava, are the main predictors of death. In the Northeast region, Cuba and Bezerra, through the study of 168 cases, described that penetrating trauma as the most frequent type in TT, the majority being treated conservatively. On the other hand, some patients required surgical specialists and a high-level trauma support hospital, which is a need not compatible with hospital services offered in this region.

Souza et al. presented in their study the profile of TT victims in the Midwest region, consisting mainly of young men with SW or motorcycle accidents. Jorge et al. showed in that same region that the total number of homicides and suicides doubled in frequency and TA are approximately $90 \%$ higher than the official report, demonstrating that TT data in Brazil is underreported.

Potlabathin and Scapolan through the analysis of 400 cases and medical records of 100 consecutive, respectively, that the TT patients profile consisted mainly of young men, with chest wall trauma, resulting from blunt TT by a TA. However, Silva and Gawryszewewski reported that the high number of trauma cases in the region can be reduced by means of accident prevention measures, investments in traffic education programs, and improvement of public safety. Mesquita Filho et al. discussed the external causes of death, which are poorly known and addressed in the public health network in the Southeast region.

Naufel Júnior, Zanette, and Oliveira in a study carried out in the South region concluded that the profile of patients affected by blunt TT consisted of men aged between 15 and 29 years. Saldanha et al. compared the use of alcohol and drugs between men and women victims of TA, showing higher incidence in TT also in men. Broska Júnior et al. stated that the chest drainage time, hospital stay, and severe complications associated are factors that worsen the prognosis of TT victims.

Guevara Rubio et al. argue that the general epidemiological profile found in Brazil is similar to that of other countries, the main difference is found in the injury mechanism. Gawryszewewski

Flowchart 1: Summarizing the search strategy for study

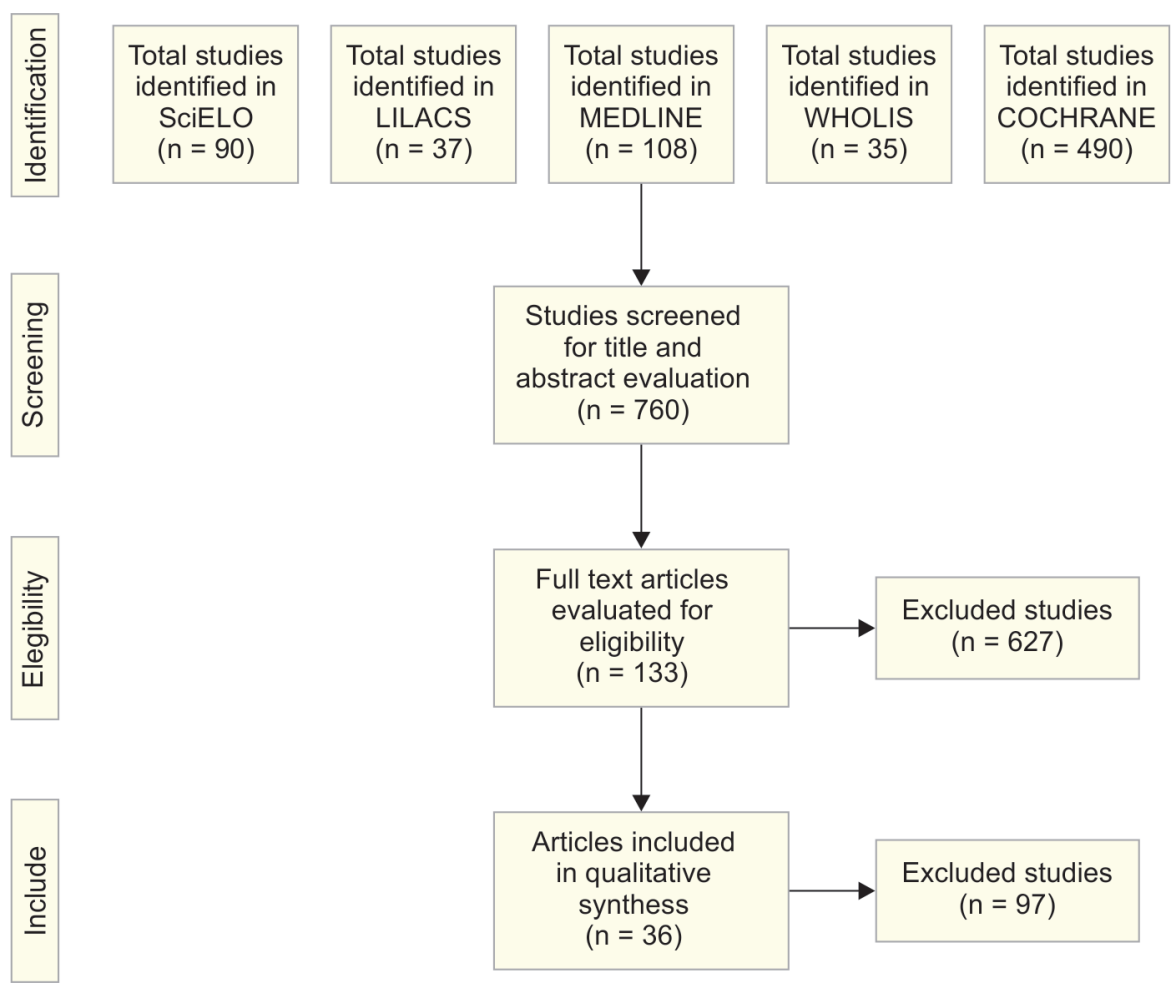


and Giannini claim that homicides and TA are the main factors for increased morbidity and mortality in Brazil. Campeão et al. add by stating that trauma is an important public health problem in Brazil, being among the main causes of death. Edgecombe and WhizarLugo described that through a diagnosis during the investigation of primary and secondary evaluation, the rate of death by TT can be reduced according to ATLS.

The division between penetrating and blunt trauma can be analyzed through the three variables selected in the study: AGRs, ISII, and TA, where the total number of deaths was $934,588(p=0.99)$. Of this total, blunt chest trauma is represented by TA, responsible for 350,684 (37.5\%) deaths being more prevalent in the Southeast $35.7 \%(p=0.033)$, likely due to greater urbanization and road stretches, followed by the Northeast $28.4 \%(p=0.99)$, South $17.4 \%$ ( $p>0.99)$, Midwest 10.6\% ( $p=0.99)$ and North 7.9\% ( $p=0.73)$. In this same perspective, penetrating trauma accounted for 583,904 (62.5\%) deaths, mainly caused by aggression (61\%) and ISII (1.5\%). Regarding deaths from aggression, the Northeast region has the highest incidence $39.9 \%$. Deaths from ISII are more common in the Southeast (37.1\%), followed by the South (27.3\%), Northeast (18.7\%), Midwest (9.8\%), and North (7.1\%) (Table 2).

Analyzed deaths in males $(826,527)$ occurred due to aggression (63.9\%), TA (34.7\%), and ISII (1.5\%). On the other hand, of the 68,550 deaths in females, the same categories represented the following figures: TA (59.6\%), AGRs (39\%), and ISII (1.5\%). However, while comparing each cause separately, it is noted that men die mainly from the three categories: aggression (92.5\%), TA (81.7\%), and ISII (88.4\%). Therefore, those male deaths occur especially by penetrating trauma (AGRs and ISII) and female deaths from blunt trauma, particularly TA (Table 2 ).

The object gunshot or stab wound (GSW/SW) used in the mechanism of open injury can be evaluated, the total of which, as previously stated, was 583,904 deaths $(p=0.99)$, and statistical analyses represented Northeast $(p=0.99)$, Southeast $(p=0.99)$, South $(p=0.04)$, North $(p=0.99)$, and Midwest $(p=0.04)$. Lesions due to GSW were responsible for $77.3 \%$ of the total number of

Table 1: Description of studies

\begin{tabular}{|c|c|c|}
\hline Author, date, citation & Theme of review & Outcomes \\
\hline Edgecombe et al., $2020^{1}$ & Thoracic trauma & $\begin{array}{l}\text { Diagnosed during the secondary trauma survey and successfully managed by } \\
\text { applying the fundamental principles of advanced trauma life support (ATLS) }\end{array}$ \\
\hline Souza et al., $2013^{2}$ & $\begin{array}{l}\text { Clinical and } \\
\text { epidemiological } \\
\text { profile }\end{array}$ & $\begin{array}{l}\text { The profile of victims of chest trauma requiring surgical care consisted mainly } \\
\text { of young men with injuries caused by stab wound or motorcycle accidents, } \\
\text { presenting hemopneumothorax or hemothorax }\end{array}$ \\
\hline Batista et al., $2006^{3}$ & $\begin{array}{l}\text { Mechanisms and } \\
\text { severity of trauma }\end{array}$ & $\begin{array}{l}\text { Traumatized, and mainly affected the lower limbs and the pelvis. Most of the } \\
\text { victims suffered superficial injuries, resulting from minor trauma }\end{array}$ \\
\hline Guevara Rubio et al., $2012^{4}$ & $\begin{array}{l}\text { Epidemiological } \\
\text { profile }\end{array}$ & $\begin{array}{l}\text { The epidemiological profile found in this study was similar to those made in other } \\
\text { countries, the main difference was found in the mechanism of injury }\end{array}$ \\
\hline Potlabathin and Kanala, $2016^{5}$ & Analysis of 400 cases & $\begin{array}{l}\text { The profile of patients with thoracic trauma is young men, with a rib fracture, } \\
\text { affected by blunt thoracic trauma due to a traffic accident }\end{array}$ \\
\hline Gawryszewewski et al., $2004^{6}$ & $\begin{array}{l}\text { Mortality and } \\
\text { morbidity }\end{array}$ & $\begin{array}{l}\text { Based on the findings, preventive programs should aim to decrease both mortality } \\
\text { and morbidity, with special emphasis on homicides, traffic accidents, and falls }\end{array}$ \\
\hline Jorge et al., $2002^{7}$ & Information systems & $\begin{array}{l}\text { The total number of homicides was five times higher; suicides doubled in } \\
\text { frequency; and transport accidents have become } 90 \% \text { more than reported by the } \\
\text { original, significantly reducing deaths from external causes of an ignored type }\end{array}$ \\
\hline Ministério da Saúde, $2000^{8}$ & $\begin{array}{l}\text { Accidents and } \\
\text { violence }\end{array}$ & Official diary of mortality and traffic violence in Brazil \\
\hline Campeão et al., $1990^{9}$ & Trauma care & $\begin{array}{l}\text { Trauma is an important public health problem in Brazil, being among the first } \\
\text { three causes of death. The trauma registry provides useful information capable of } \\
\text { improving care for victims, defining preventive measures, providing information } \\
\text { for the application of resources }\end{array}$ \\
\hline Scapolan et al., $2010^{10}$ & $\begin{array}{l}\text { Analysis of } 100 \text { con- } \\
\text { secutive cases }\end{array}$ & $\begin{array}{l}\text { The thoracic trauma patient is most prevalently young male with stab wound } \\
\text { penetrating injury, without associated injuries, hemodynamically stable, } \\
\text { presenting hemothorax, with a high probability of survival }\end{array}$ \\
\hline Fontelles and Mantovani, $2000^{11}$ & Thoracic trauma & $\begin{array}{l}\text { In the multivariate logistic regression analysis, the variables length of stay, } \\
\text { blunt trauma, and blood volume drained }>500 \mathrm{~mL} \text {, when associated, positively } \\
\text { influenced the occurrence of complications }\end{array}$ \\
\hline Calhoon and Trinkle, $1997^{12}$ & $\begin{array}{l}\text { Chest trauma patho- } \\
\text { physiology }\end{array}$ & $\begin{array}{l}\text { Molecular generic response to injury that can lead to multiorgan failure. For many } \\
\text { years, basic physiology and biochemistry were considered to be the systemic } \\
\text { mechanisms of injury }\end{array}$ \\
\hline Silas et al., $1990^{13}$ & Thoracic injuries & $\begin{array}{l}\text { Study reports the treatment of patients in the emergency system for thoracic } \\
\text { trauma }\end{array}$ \\
\hline Symbas, $1989^{14}$ & Chest drainage & $\begin{array}{l}\text { Tube thoracostomy results in complete drainage of the collected air and fluid in } \\
\text { the pleural space and allows full expansion and occupation of the entire pleural } \\
\text { space by the lung, thus protecting the lung and pleural space from subsequent } \\
\text { complications }\end{array}$ \\
\hline
\end{tabular}


Contd...

\begin{tabular}{|c|c|c|}
\hline Author, date, citation & Theme of review & Outcomes \\
\hline Westphal and Luiz, $2009^{15}$ & Thoracic trauma & $\begin{array}{l}\text { The most contributing death factors were the lethal anatomical score, }>15 \text { points, } \\
\text { and the association with major vascular lesions, like the aorta and vena cava }\end{array}$ \\
\hline $\begin{array}{l}\text { American College of Surgeons, } \\
2018^{16}\end{array}$ & $\begin{array}{l}\text { Student course } \\
\text { manual }\end{array}$ & ATLS 10th ed. \\
\hline Whizar-Lugo et al., $2015^{17}$ & Chest trauma & $\begin{array}{l}\text { Chest trauma is a modern major health problem with high mortality, even in } \\
\text { trauma center hospitals. It is a life-threatening condition, which often involves } \\
\text { other anatomical regions that merit simultaneous diagnosis and treatment }\end{array}$ \\
\hline Giannini et al., $2001^{18}$ & Chest trauma & $\begin{array}{l}\text { Thoracic trauma is still frequent, and the majority of cases are simple. On the other } \\
\text { hand, some will require surgical skill and a high-level support hospital }\end{array}$ \\
\hline Naufel Júnior et al., $2014^{19}$ & $\begin{array}{l}\text { Thoracic trauma } \\
\text { profile }\end{array}$ & $\begin{array}{l}\text { Men aged between } 15 \text { and } 29 \text { years were the most affected, submitted to pleural } \\
\text { drainage due to blunt trauma, most often associated with hemopneumothorax }\end{array}$ \\
\hline Aucar et al., $2007^{20}$ & $\begin{array}{l}\text { Trauma computed } \\
\text { tomography }\end{array}$ & $\begin{array}{l}\text { Increasing use of multi-image studies is facilitated by improvements in technology } \\
\text { and medical-legal pressures. However, extensive imaging can stress overburdened } \\
\text { trauma systems }\end{array}$ \\
\hline Brink et al., $2010^{21}$ & $\begin{array}{l}\text { Blunt trauma pa- } \\
\text { tients }\end{array}$ & $\begin{array}{l}\text { Selective } C T \text { results in less radiation dose exposure but a slightly higher cost and } \\
\text { less certainty }\end{array}$ \\
\hline Fenili et al., $2002^{22}$ & Thoracic trauma & $\begin{array}{l}\text { Discussion of the main types of injuries and injuries resulting from chest trauma } \\
\text { found }\end{array}$ \\
\hline Rowan et al., $2002^{23}$ & $\begin{array}{l}\text { Traumatic pneumo- } \\
\text { thorax detection }\end{array}$ & $\begin{array}{l}\text { Us was more sensitive than supine chest radiography and as sensitive as CT in the } \\
\text { detection of traumatic pneumothoraces }\end{array}$ \\
\hline Flato et al., $2010^{24}$ & $\begin{array}{l}\text { EFAST-extended } \\
\text { focused assessment }\end{array}$ & $\begin{array}{l}\text { This type of complementary exam replaces computed tomography and diagnostic } \\
\text { peritoneal lavage }\end{array}$ \\
\hline $\begin{array}{l}\text { Secretaria de Assuntos Estratégi- } \\
\cos , 2015^{25}\end{array}$ & $\begin{array}{l}\text { Traffic accidents } \\
\text { on Brazilian federal } \\
\text { highways }\end{array}$ & Numerical data from the federal police on traffic accidents in brazil \\
\hline Zanette et al., $2019^{26}$ & $\begin{array}{l}\text { Epidemiological } \\
\text { profile of thoracic } \\
\text { trauma }\end{array}$ & $\begin{array}{l}\text { Chest } X \text {-ray was used to confirm most of the diagnoses, and there was a } \\
\text { prevalence for conservative treatment }\end{array}$ \\
\hline Mesquita Filho et al., $2007^{27}$ & $\begin{array}{l}\text { Morbidity due to } \\
\text { external causes at } \\
\text { emergencies }\end{array}$ & Status of external causes is very little known and approached in public health \\
\hline Silva et al., $2017^{28}$ & $\begin{array}{l}\text { Valence and epide- } \\
\text { miological profile of } \\
\text { trauma }\end{array}$ & $\begin{array}{l}\text { A high number of trauma cases in Paracatu-MG, which demonstrates the need } \\
\text { for measures to prevent domestic accidents, investments in traffic education } \\
\text { programs, and improvement of public safety }\end{array}$ \\
\hline Cuba and Bezerra, $2005^{29}$ & Study of 168 cases & $\begin{array}{l}\text { Thoracic trauma is still frequent, and the majority of cases are simple. On the other } \\
\text { hand, some will require surgical skill and a high-level support hospital }\end{array}$ \\
\hline Broska Júnior et al., $2017^{30}$ & Thoracic trauma & $\begin{array}{l}\text { The time of drainage, hospitalization, and complications were higher than in the } \\
\text { literature, which can be explained by the drainage being made at the emergency } \\
\text { room and the presence of associated injuries }\end{array}$ \\
\hline Mahran et al., $2016^{31}$ & $\begin{array}{l}\text { Thoracic injuries and } \\
\text { trauma }\end{array}$ & $\begin{array}{l}\text { Increasing the awareness of the community, making policies, and establishment of } \\
\text { a trauma system are important to decrease the burden of injuries }\end{array}$ \\
\hline Oliveira et al., $2017^{32}$ & $\begin{array}{l}\text { Mortality in traffic } \\
\text { accidents }\end{array}$ & $\begin{array}{l}\text { Hospitalization rate due to trauma in Brazil may be the result of some factors, such } \\
\text { as an increasing number of accidents and cases of violence }\end{array}$ \\
\hline Saldanha et al., $2014^{33}$ & $\begin{array}{l}\text { Victims of traffic ac- } \\
\text { cidents }\end{array}$ & $\begin{array}{l}\text { Compare alcohol and drug use among men and women who were the victims of } \\
\text { traffic accidents }\end{array}$ \\
\hline Spencer Netto et al., $2001^{34}$ & $\begin{array}{l}\text { Predictors of mortal- } \\
\text { ity }\end{array}$ & $\begin{array}{l}\text { The majority of patients treated for cardiac injuries presented good predictors for } \\
\text { survival, justifying our low mortality rates }\end{array}$ \\
\hline Cerqueira et al., $2015^{35}$ & Firearms maps & Map of firearm deaths in Brazil, the federal government \\
\hline Ministério da Saúde 36 & SIM-SUS & Unique health system, the federal government \\
\hline
\end{tabular}

Description of all articles selected for analysis.

penetrating chest trauma deaths and accounted for $79.3 \%$ of male deaths (Table 3).

From the GSW deaths, the Northeast is the main representative $(41.1 \%)$, followed by the Southeast (28.2\%), South (12\%), North (10.2\%), and Midwest (8.3\%). Those caused by SW totaled $22.1 \%$, which represents $86.7 \%$ of deaths in that region. The distribution between the regions is as follows: Northeast (33.1\%), Southeast (26.8\%), North (16.4\%), South (12\%), and Midwest (11.5\%). In fact, according to female deaths, $60.9 \%$ were caused by GSW and $39.1 \%$ by SW. 
Table 2: Deaths from external causes in Brazilian regions

\begin{tabular}{|c|c|c|c|c|c|c|}
\hline \multirow[b]{2}{*}{ Brazilian region } & \multicolumn{6}{|c|}{ Large group ICD-10 } \\
\hline & Sex & TA & $I S I I$ & AGRs & Total & Statistic \\
\hline \multirow[t]{4}{*}{ North } & Male & 22.778 & 867 & 62.243 & 85.888 & $p=0.73$ \\
\hline & Female & 5.005 & 98 & 4.519 & 9.622 & \\
\hline & $\mathrm{Ne}$ & 28 & 0 & 118 & 146 & \\
\hline & Total & 27.811 & 965 & 66.880 & 95.656 & \\
\hline \multirow[t]{4}{*}{ Northeast } & Male & 84.256 & 2.312 & 212.895 & 299.463 & $p=0.99$ \\
\hline & Female & 15.254 & 234 & 14.309 & 29.797 & \\
\hline & $\mathrm{Ne}$ & 42 & 0 & 181 & 223 & \\
\hline & Total & 99.552 & 2.546 & 227.385 & 329.483 & \\
\hline \multirow[t]{4}{*}{ Southeast } & Male & 101.202 & 4.444 & 144.744 & 250.390 & $p=0.033$ \\
\hline & Female & 24.062 & 620 & 13.008 & 37.690 & \\
\hline & $\mathrm{Ne}$ & 67 & 0 & 183 & 250 & \\
\hline & Total & 125.331 & 5.064 & 157.935 & 288.330 & \\
\hline \multirow[t]{4}{*}{ South } & Male & 48.539 & 3.253 & 60.674 & 112.466 & $p>0.99$ \\
\hline & Female & 12.354 & 472 & 5.733 & 18.559 & \\
\hline & $\mathrm{Ne}$ & 17 & 0 & 39 & 56 & \\
\hline & Total & 60.910 & 3.725 & 66.446 & 131.081 & \\
\hline \multirow[t]{4}{*}{ Midwest } & Male & 29.821 & 1.195 & 47.304 & 78.320 & $p=0.99$ \\
\hline & Female & 7.248 & 146 & 4.244 & 11.638 & \\
\hline & $\mathrm{Ne}$ & 11 & 0 & 69 & 80 & \\
\hline & Total & 37.080 & 1.341 & 51.617 & 90.038 & \\
\hline \multirow[t]{4}{*}{ Total general } & Male & 286.596 & 12.071 & 527.860 & 826.527 & $p=0.99$ \\
\hline & Female & 63.923 & 1.570 & 41.813 & 107.306 & \\
\hline & $\mathrm{Ne}$ & 165 & 0 & 590 & 755 & \\
\hline & Total & 350.684 & 13.641 & 570.263 & 934.588 & \\
\hline
\end{tabular}

Death by Region: Large group ICD-10: TA, Traffic accidents; ISII, Intentional Self-inflicted injuries; AGRs, Aggressions

Source: MS/SVS/CGIAE—Mortality Information System—SIM

Period: $2008-2018$

In that sense, it is noted that lesions by GSW are the most prevalent in both sexes and the Northeast has the higher prevalence of the two categories (Table 3).

\section{Discussion}

In TT, the determining injuries for immediate risk of death are airway obstruction, hypertensive pneumothorax, open pneumothorax, cardiac tamponade, tracheobronchial injury, and massive hemothorax. Those with a potential risk of death and should be diagnosed and treated on secondary evaluation are pneumothorax, hemothorax, pulmonary contusion, flail chest, blunt heart trauma, traumatic aorta rupture, and traumatic rupture of the diaphragm. ${ }^{16}$ Hence, penetrating or blunt chest trauma, as long as it is associated with these consequences of chest trauma, is subject to higher mortality as chest injuries correspond to the highest death rate during primary evaluation.

Lesions can also be divided into four large groups of associated injuries: chest wall, pulmonary, mediastinal, and diaphragmatic lesions. ${ }^{17}$ These lead to six main types of clinical situations: airway obstruction, hypertensive pneumothorax, flail chest, cardiac tamponade, open pneumothorax, and massive hemothorax. ${ }^{16}$ In addition, abdominal organs may also be affected - such as the liver and spleen-more often in thoracoabdominal or those due to a high energy mechanism. ${ }^{18}$ Therefore, early diagnosis and treatment are essential in the first hour of trauma (Golden Hour) and are associated with lower morbidity and mortality. ${ }^{1,16,19}$

Chest computed tomography (CT) is considered a more sensitive method and should be used only in special situations and for stable patients. ${ }^{20,21}$ The gold standard in the care of TT for blood detection in the pleural cavity and pericardium has been extended focused assessment with sonography for the trauma (E-FAST) ${ }^{16,22}$ It can also be used in the detection of pneumothorax, with sensitivity similar to that of chest CT and higher than chest X-ray. ${ }^{22-24}$

Of the total deaths in trauma patients, $25-35 \%$ are caused by $\mathrm{TT}^{1,2}$ The mortality with only one isolated chest injury ranges from 4 to $8 \%$, however, it rises to $25 \%$ when another organ is reached and up to $35 \%$ when multiple organs are hit. ${ }^{13}$ Thus, according to the Brazilian Ministry of Health, about 30,150 trauma patients die during surgical treatment during the analyzed period (2008-2018). Therefore, it is concluded that, of this total, $>10,000$ people died from chest trauma in these 10 years.

In TT, $85 \%$ of victims normally are treated under ventilatory support, analgesia, and chest tube thoracostomy. Only 15-30\% will require surgical treatment, in most cases severe patients who need some type of intervention, a fact that justifies the demand for trauma centers. ${ }^{10,15,18}$

According to the Institute for Applied Economic Research (IPEA), in 2004 TA increased by $50.3 \%$ on Federal Highways, with a rise of $34.5 \%$ in deaths and $50 \%$ in general injuries. However, between 2010 
Table 3: Deaths from penetrating blunt chest trauma in Brazilian regions

\begin{tabular}{|c|c|c|c|c|c|c|c|c|}
\hline \multirow{2}{*}{$\begin{array}{l}\text { Brazilian } \\
\text { Region } \\
\end{array}$} & \multicolumn{8}{|c|}{ Category ICD10 } \\
\hline & Sex & GSW & $S W$ & Total & & GSW (\%) & $S W(\%)$ & Total (\%, \\
\hline \multirow[t]{4}{*}{ North } & Male & 43.975 & 19.135 & 63.110 & $p=0.89$ & 69.7 & 30.3 & 100 \\
\hline & Female & 2.604 & 2.013 & 4.617 & & 56.4 & 43.6 & 100 \\
\hline & $\mathrm{Ne}$ & 63 & 55 & 118 & & 53.4 & 46.6 & 100 \\
\hline & Total & 46.642 & 21.203 & 67.845 & & 68.7 & 31.3 & 100 \\
\hline \multirow[t]{4}{*}{ Northeast } & Male & 177.378 & 37.829 & 215.207 & $p=0.99$ & 82.4 & 17.6 & 100 \\
\hline & Female & 9.700 & 4.843 & 14.543 & & 66.7 & 33.3 & 100 \\
\hline & $\mathrm{Ne}$ & 113 & 68 & 181 & & 62.4 & 37.6 & 100 \\
\hline & Total & 187.191 & 42.740 & 229.931 & & 81.4 & 18.6 & 100 \\
\hline \multirow[t]{4}{*}{ Southeast } & Male & 120.459 & 28.729 & 149.188 & $p=0.99$ & 80.7 & 19.3 & 100 \\
\hline & Female & 7.798 & 5.830 & 13.628 & & 57.2 & 42.8 & 100 \\
\hline & $\mathrm{Ne}$ & 152 & 31 & 183 & & 83.1 & 16.9 & 100 \\
\hline & Total & 128.409 & 34.590 & 162.999 & & 78.8 & 21.2 & 100 \\
\hline \multirow[t]{4}{*}{ South } & Male & 50.697 & 13.230 & 63.927 & $p=0.04$ & 79.3 & 20.7 & 100 \\
\hline & Female & 3.872 & 2.333 & 6.205 & & 62.4 & 37.6 & 100 \\
\hline & $\mathrm{Ne}$ & 34 & 5 & 39 & & 87.2 & 12.8 & 100 \\
\hline & Total & 54.603 & 15.568 & 70.171 & & 77.8 & 22.2 & 100 \\
\hline \multirow[t]{4}{*}{ Midwest } & Male & 35.555 & 12.944 & 48.499 & $p=0.04$ & 73.3 & 26.7 & 100 \\
\hline & Female & 2.457 & 1.933 & 4.390 & & 56.0 & 44.0 & 100 \\
\hline & $\mathrm{Ne}$ & 34 & 35 & 69 & & 49.3 & 50.7 & 100 \\
\hline & Total & 38.046 & 14.912 & 52.958 & & 71.8 & 28.2 & 100 \\
\hline \multirow[t]{4}{*}{ Total general } & Male & 428.064 & 111.867 & 539.931 & $p=0.99$ & 79.3 & 20.7 & 100 \\
\hline & Female & 26.431 & 16.952 & 43.383 & & 60.9 & 39.1 & 100 \\
\hline & $\mathrm{Ne}$ & 396 & 194 & 590 & & 67.1 & 32.9 & 100 \\
\hline & Total & 454.891 & 129.013 & 583.904 & & 77.9 & 22.1 & 100 \\
\hline
\end{tabular}

Category ICD-10 including summation (ISII and AGRs): (GSW) gunshot: injury firing handgun; gunshot firing weapon over caliber; injury firing another firearm and unspecified; handgun shooting; firing gunfire of greater caliber; Aggression firing another firearm or unspecified; (SW) non-gunshot: injury penetrating cutting object; Aggression sharp or penetrating object; Injury by a blunt object; Aggression by means of a blunt object

Source: MS/SVS/CGIAE—Mortality Information System—SIM

Period: $2008-2018$

and 2014, there was a reduction from 40 to $30 \%$ in the number of accidents and serious victims. ${ }^{25}$ This information corroborates the results of TA found in our study, although the number is smaller, it is still necessary to reduce it even more. In Itajaí, a municipality in the state of Santa Catarina (South region), in 2019, $89 \%$ of TT were due to blunt injuries and $57 \%$ to TA. ${ }^{26}$

Penetrating TT was responsible for more than half of the deaths from TT assessed, mainly due to external causes. A study published in 2009, points out that in Manaus (North region), TT occurred mainly owing to physical aggression, especially in males $(98.8 \%){ }^{15}$ This fact corroborates with the results found in our study because the AGRs overcame self-harm and TA in the North of the country. Our data are in agreement with other studies carried out in São Paulo, Minas Gerais, Goiás, Paraná, and Maranhão, where penetrating trauma was predominant, mainly in males. ${ }^{2,10,27-30}$

The high prevalence of TT in males between 20 years and 40 years may not represent greater access to health services, but a greater tendency to exposure to external causes. ${ }^{31,32}$ Besides that, a study carried out in two hospitals in Porto Alegre compared risk behavior among men and women involved in TA. Such a study revealed that $70 \%$ of the 609 victims were men, and of these, $75.2 \%$ were drivers and only $18.6 \%$ of women involved in accidents were female drivers. Evidence pointed to higher use of alcohol, marijuana, and cocaine among men and higher use of anxiolytics among women. ${ }^{33}$ Thus, males tend to be affected more by TA and get involved in violent situations, when compared to females.

In penetrating TT, there is a relationship between the type of weapon and the economic conditions of the study population. Stab wound predominates in poorer regions compared to the GSW. ${ }^{15}$ Literature data revealed a prevalence of penetrating trauma by GSW in Manaus, São Paulo, Goiânia, Recife, São Luis, and Itajaí. 2,10,15,26,30,34

The high rate of deaths by GSW and the difference between the Northeast and Southeast in deaths can be understood. According to IPEA, in 2010, in 20 microregions with the largest number of firearms in Brazil, 13 were located in the Northeast, 4 in the Southeast, 2 in the South, and 1 in the North. This fact confirms the distribution by regions regarding deaths to GSW. It is notable that, even after the Disarmament Statute in 2003 — which prohibited the commercialization of firearms throughout Brazil-the reduction in the use of firearms has not occurred homogeneously in the country. ${ }^{35}$

Through the data obtained by the SIM system, referring to "Deaths due to External Causes in the Brazilian Regions", according to the analyses of TA, ISII, and AGRs, the only region that presented statistical relevance was Southeast presenting $(p=0.033)$ due to the extensive road providing a large number of TA. The North Region, although presenting a high rate of AGRs and with low population concentration and low income, did not demonstrate statistical 
relevance ( $p=0.73$ ). For the other regions, there was no statistical significance $(p \geq 0.5)$.

On the other hand, while analyzing deaths for penetrating TT in the Brazilian region, we found statistical relevance for GSW and SW in the South ( $p=0.04)$ and the Midwest $(p=0.04)$ among the other regions, although the statistical significance is irrelevant $(p \geq 0.5)$.

During the literature search for this systematic review, the deficiency of data compilation was an important and present factor observed by the authors. In Brazil, there is no consistent database that presents reliable information about TT. The main studies on chest issues are descriptors of surgical procedures and techniques, leaving a gap on the epidemiology and specific characteristics of TT in Brazil. Thus, in this study, we seek to present the main epidemiological characteristics of TT in the country to fill this need by offering concisely compiled information.

\section{Conclusion}

According to our analysis, TT is more prevalent in males. The most common type is penetrating TT and the highest mortality occurred due to GSW. As for blunt traumas, they are mainly caused by TA.

There is a need for a more accurate compilation of specific data regarding TT to ensure a safer epidemiological panorama since in Brazil the characteristics of TT are heterogeneous and thus, the lack of reliable data can demonstrate a fictitious reality of information.

\section{Contributorship Statement}

All Authors equally contributed to the execution of this text, discuss planning, conduct, reporting, conception and design, acquisition of data, analysis, and interpretation of data: Gabriel Antonio Roberto, Carolina Magalhães Britto Rodrigues, Sthefano Atique Gabriel, and Rodrigo Sardenberg.

\section{References}

1. Edgecombe L, Sigmon DF, Angus LD. Thoracic trauma. Treasure Island (FL): StatPearls Publishing; 2020. Jan last Update: January 31, 2020.

2. Souza VS, Santos AC, Pereira LV, et al. Clinical and epidemiological profile of victims of chest trauma undergoing surgical treatment at a referral hospital. Clinical and epidemiological profile of victims of chest trauma undergoing surgical. treatment at a referral hospital. Sci Med 2013(2):96-101.

3. Batista SEA, Baccani JG, Silva RAP, et al. Análise comparativa entre os mecanismos de trauma, as lesões e o perfil de gravidade das vítimas, em Catanduva - SP. Rev Col Bras Cir 2006;33(1):6-10. DOI: https://doi. org/10.1590/S0100-69912006000100003.

4. Guevara Rubio N, Olivarec Bonilla M, Ortega Sánchez R. Perfil epidemiológico del paciente con trauma de tórax em el Servicio de Urgencias Adultos del Hospital. General Archivos de Medicina de Urgencia de México 2012;4(3):105-111.

5. Potlabathin RP, Kanala A. Experience with chest trauma: analysis of 400 cases. J Evid Based Med Healthc 2016;3(73):3986-3989. DOI: 10.18410/jebmh/2016/852.

6. Gawryszewewski VP, Koizumi MS, Jorge MHPM. As causas externas no Brasil no ano 2000: comparando a mortalidade e a morbidade. Cad Saúde Pública (Rio de Janeiro) 2004;20(4):995-1003. DOI: http:// dx.doi.org/10.1590/S0102- 311X2004000400014.

7. Jorge MHPM, Gotlieb SLD, Laurenti R. O sistema de informações sobre mortalidade: problemas e propostas para o seu enfrentamento II - Mortes por causas externas. Rev Bras Epidemiol (São Paulo) 2002;5(2):212-223. DOI: http://dx.doi.org/10.1590/S1451$790 \times 2002000200008$.
8. Ministério da Saúde. Política nacional de redução da morbimortalidade por acidentes e violência. Rev Saúde Pública (São Paulo) 2000;34(4):427-430. DOI: http://dx.doi.org/10.1590/ S0034-89102000000400020.

9. Campeão HR, Copes WS, Sacco WJ, et al. Estudo dos principais resultados do trauma: estabelecendo normas nacionais para atendimento ao trauma. J Trauma 1990;30(11):1356-1365. DOI: 10.1097/00005373-199011000-00008.

10. Scapolan MB, Vieira NLP, Nitrini SS, et al. Thoracic trauma: analysis of 100 consecutive cases. Einstein (São Paulo) 2010;8(3):339-342. DOI: 10.1590/s167945082010ao1532.

11. Fontelles MJP, Mantovani M. Trauma torácico: fatores de risco de complicações pleuropulmonares pós-drenagem pleural fechada. Rev Col Bras Cir 2000;27(6):400-407. DOI: 10.1590/S010069912000000600008

12. Calhoon JH, Trinkle JK. Pathophysiology of chest trauma. Chest Surg Clin N Am 1997;7:199-211.

13. Silas MG, Belluzzo BR, Miguel EG. Thoracic injuries - review of 231 cases. Arq Med ABC 1990;13(1-2):19-21.

14. Symbas PN. Chest drainage tubes. Surg Clin North Am 1989;69(1):4146. DOI: 10.1016/S0039-6109(16)44733-X.

15. Westphal, Luiz F. Trauma torácico: análise de 124 pacientes submetidos à toracotomia. Rev Col Bras Cir 2009;36(6):482-486. DOI: 10.1590/S0100-69912009000600004.

16. American College of Surgeons. ATLS: advanced trauma life support for doctors: student course manual. 10th ed., Chicago (IL): American College of Surgeons; 2018.

17. Whizar-Lugo V, Sauceda-Gastelum A, Hernández-Armas A, et al. Chest trauma: an overview. J Anesth Crit Care Open Acess 2015;3(1):2-11.

18. Giannini JÁ, Soldá SC, Saad Júnior R. Trauma de tórax. in Emergências Traumáticas e Não Traumáticas, ed. Coimbra RSM, Soldá SC, Casaroli AA, et al. São Paulo: Atheneu; 2001. pp. 57-69.

19. Naufel Júnior $C R$, Talini C, Barbier Neto L. Thoracic trauma profile of attended victims at Hospital Universitário Evangélico De Curitiba (HUEC). Rev Med UFPR 2014;1(2):42-46. DOI: 10.5380/rmu.v1i2.40701.

20. Aucar JA, Fernandez L, Wagner-Mann C. If a picture is worth a thousand words, what is a trauma computerized tomography panel worth. Am J Surg 2007;194(6):734-739. DOI: 10.1016/j. amjsurg.2007.08.036discussion 739-40.

21. Brink M, Deunk J, Dekker HM, et al. , Criteria for the selective use of chest computed tomography in blunt trauma patients. Eur Radiology 2010;20(4):818-828. DOI: 10.1007/s00330-009-1608-y.

22. Fenili R, Alcacer JAM, Cardona MC. Traumatismo torácico: uma breve revisão. Arq Catarin Med 2002;31(1-2):31-36.

23. Rowan KR, Kirkpatrick AW, Liu D, et al. Traumatic pneumothorax detection with thoracic US: correlation with chest radiography and CT - initial experience. Radiology 2002;225(1):210-214. DOI: 10.1148/ radiol.2251011102.

24. Flato UPF, Guimarães HP, Lopes RD, et al. Usefulness of extended-FAST (EFAST-extended focused assessment with sonography for trauma) in critical care setting. Rev Bras Ter Intensiva 2010;22(3). DOI: 10.1590/ S0103-507X2010000300012.

25. BRASIL. Secretaria de Assuntos Estratégicos da Presidência da República. Instituto de Pesquisa Econômica Aplicada. Acidentes de trânsito nas rodovias federais brasileiras: caracterização, tendências e custos para a sociedade. Brasília, 2015 jul 20. Disponível em: http://www.ipea.gov.br/portal/index.php?option=com content\&view $=$ article\&id=2627. [access april, 2020].

26. Zanette GZ, Waltrick RS, Monte MB. Epidemiological profile of thoracic trauma in a reference hospital of Foz do Rio Itajai. Rev Col Bras Cir 2019;46(2). DOI: 10.1590/0100-6991e-20192121.

27. Mesquita Filho M, Mesquita Filho J, Mello MHP. Features of morbidity due to external causes at emergency services. Rev Bras Epidemiol 2007;10(4):579-591. DOI: 10.1590/S1415-790X2007000400016.

28. Silva LAP, Ferreira AC, Paulino RES, et al. Retrospective analysis of the prevalence and epidemiological profile of trauma patients in a secondary hospita. Rev Med 2017;96(4):246-253. DOI: 10.11606/ issn.1679-9836.v96i4p246-254. 
29. Cuba RMBF, Bezerra JAF. Thoracic trauma: retrospective study of 168 cases. Rev Col Bras Cir 2005;32(2):57-59. DOI: 10.1590/S010069912005000200002.

30. Broska Júnior $C A$, Botelho $A B$, Linhares $A C$, et al. Perfil das pacientes vítimas de trauma torácico submetidos à drenagem de tórax. Rev Col Bras Cir 2017;44(1). DOI: 10.1590/0100-69912017001005.

31. Mahran DG, Farouk O, Qayed MH, et al. Pattern and trend of injuries among trauma unit attendants in upper Egypt. Traum Mon 2016;21(2):e20967. DOI: 10.5812/traumamon.20967.

32. Oliveira NLB, Souza EM, Cunha GZ. Mortality in traffic accidents: temporary trend between 1996 and 2012. Cien Cuid Saude 2017;16(4). DOI: 10.4025/cienccuidsaude.v16i4.38343.

33. Saldanha RF, Pechansky F, Benzano D, et al. Differences between attendance in emergency care of male and female victims of traffic accidents in Porto alegre, Rio Grande do Sul state, Brazil. Cien
Saude Colet 2014;19(9):3925-3930. DOI: 10.1590/1413-81232014199. 12892013.

34. Spencer Netto FAC, Campos JM, Lima LFC, et al. Predictors of mortality in patients with cardiac trauma who arrive alive in the operation room. Rev Col Bras Cir 2001;28(2):87-94. DOI: 10.1590/ S0100-69912001000200003.

35. Cerqueira D, Coelho D, Siqueira R, Brasil, Secretaria de Assuntos Estratégicos da Presidência da República. Instituto de Pesquisa Econômica Aplicada. Mapas de Armas de Fogo nas Microrregiões Brasileiras. Brasília, 2015 jul 20. Disponível em: https://ipea.gov.br/ agencia/images/stories/PDFs/relatoriopesquisa/mapaarmas.pdf. [access april, 2020].

36. Brasil, Ministério da Saúde. Banco de dados do Sistema Único de Saúde-SIM. Disponível em http://www.datasus.gov.br [access april, 2020]. 